\title{
MODERASI INFLASI PADA PENGARUH DIVIDEND PAYOUT RATIO (DPR) DAN RETURN ON EQUITY (ROE) TERHADAP RETURN SAHAM
}

\author{
Ni Nyoman Sri Rahayu Trisna Dewi ${ }^{1}$ \\ Universitas Triatma Mulya ${ }^{1}$ \\ email: rahayutrisna333@gmail.com
}

\begin{abstract}
Investors definitely expect a high return on the investment made. To obtain a high return, investors need to analyze the investment they are making. The analysis carried out can be a fundamental analysis that assesses the company's financial capacity by looking at financial reports. Fundamental analysis can be done by assessing the DPR and ROE produced by the company. Apart from fundamental analysis, investors also need to pay attention to macro factors such as inflation that can affect their investment. This study aims to determine the effect of DPR and ROE partially on stock returns and to determine the moderation of inflation in each of the effects of DPR and ROE on stock returns. The object of this research are companies listed on the LQ45 index for the 2018-2019 period. The sample method used was purposive sampling in order to obtain a sample size of 40 samples. The data analysis technique used moderate regression analysis. The results showed that the DPR did not have a significant effect on stock returns while ROE had a positive and significant effect on stock returns. The results also show that inflation does not moderate the respective effects of DPR and ROE on stock returns.
\end{abstract}

Keywords: DPR, ROE, Inflation, Stock Returns

\section{PENDAHULUAN}

Setiap investor pasti ingin memperoleh pengembalian (return) yang besardaridana yang diinvestasikan. Pada investasi saham, return yang diperoleh oleh investor dapat berupa capital gain dan dividen. Capital gainadalah selisih harga beli dan harga jual saham, sedangkan dividen merupakan pembagian hasil yang diberikan secara proporsional oleh perusahaan kepada pemilik atau pemegang saham, sesuai dengan persentase kepemilikan sahamnya. Return yang dapat diperoleh oleh investor saham jumlahnya bervariasi. Investor dapat memperoleh return saham yang tinggi, dan dapat memperoleh return yang rendah. Besar kecilnya return saham yang diperoleh oleh investor dapat dipengaruhi olehReturn On Equity (ROE) (Devi dan Artini, 2019).Return saham juga dapat dipengaruhi oleh Divident Payout Ratio (DPR) (Pratiwi, 2015).

$$
\text { Return On Equity (ROE) }
$$
merupakan rasio yang digunakan untuk menilaikemampuan manajemen suatu perusahaan dalam mengelola modal yang tersedia untukmendapatkan net income (Wijaya, 2019). Hutami (2012) menyatakan kenaikan ROE biasanya diikuti dengan kenaikan harga saham 
perusahaan tersebut. Nilai ROE yang tinggi berarti perusahaan memiliki kinerja yang baik dalam mengelola modalnya untuk menghasilkan laba bagi para pemegang saham. Perusahaan yang menghasilkan laba bersih yang tinggi, akan menghasilkan nilai ROE yang tinggi juga. Hal tersebut akan meningkatkan kepercayaan investor untuk berinvestasi pada perusahaan dengan ekspektasi akan memperoleh return yang tinggi pula. Perusahaan yang memiliki nilai ROE yang tinggi, mengindikasikan kinerja perusahaan yang baik dalam halpengelolaan modalnya untuk menghasilkan keuntungan bagi pemegang saham. Hal tersebut akan menarik minat investor untuk menanamkan modal di perusahaan tersebut.

Persentase dari laba yang akan dibayarkan kepada pemegang saham sebagai dividen tunai disebut Dividend Payout Ratio (DPR). DPR mencerminkan perbandingan antara dividen per share dan earning per share. DPR disajikan dalam bentuk persentase yang menggambarkan perbandingan dividen yang didapatkan dari laba bersih. Fidrian dkk (2018) menyatakan dividen merupakan salah satu hal yang diinginkan investor dalam berinvestasi di pasar modal. Jika dividen yang diperoleh tidak memenuhi harapan, investor cenderung tidak tertarik untuk membeli atau mempertahankan saham yang dimiliki. Dengan demikian, semakin tinggi DPR yang dimiliki oleh perusahaan maka semakin tinggi jumlah laba yang akan dibagikan sebagai dividen pada pemegang saham. Hal tersebut akan meningkatkan return saham yang diperoleh investor.

Investor akan memilih perusahaan dengan profitabilitas yang tinggi dalam berinvestasi dengan harapan mereka akan memperoleh return saham yang tinggi. Namun tidak dapat dipungkiri dalam berinvestasi, seorang investor juga harus menilai pertumbuhan inflasi yang terjadi. Karena meskipun perusahaan memberikan return yang tinggi namun jika lebih rendah dari nilai inflasi, maka investor akan berfikir kembali untuk berinvestasi di perusahaan tersebut. Inflasi juga menjadi salah satu penyebab utama yang memotivasi investor untuk berinvestasi. Investasi dilakukan untuk melindungi nilai internal aset yang dimiliki dari tingkat inflasi sehingga mereka dapat mempertahankan daya beli barang yang mereka miliki saat ini. Tingkat inflasi yang tinggi menunjukkanbahwa resiko investasi cukup besar karena inflasiyang tinggi akan mengurangi tingkat pengembalian (rate of return) yang diperoleh investor. Di Indonesia, tingkat inflasi mengalami fluktuasi dari tahun ke tahun seperti yang tersaji pada Tabel 1 . 


\section{Fluktiasi Tingkat Inflasi Tahun 2016-2019}

\begin{tabular}{ll}
\hline Tahun & $\begin{array}{l}\text { Tingkat } \\
(\boldsymbol{\%})\end{array}$ \\
\hline 2016 & 3,02 \\
2017 & 3,61 \\
2018 & 3,13 \\
2019 & 2,72 \\
\hline
\end{tabular}

Sumber: www.bps.go.id, 2019

Berdasarkan Tabel 1 dapat dilihat bahwa inflasi yang terjadi di Indonesia mengalami fluktuasi dalam 4 tahun terakhir. Namun angka yang ditunjukan berada di bawah $10 \%$, artinya bahwa inflasi yang terjadi di Indonesia merupakan inflasi ringan. Tandelilin (2010) menyatakan bahwa inflasi adalah kecenderungan peningkatan harga produk secara keseluruhan. Inflasi yang tinggi dapat mengurangi tingkat pendapatan riil yang diperoleh investor dari investasi (Suriyani dan Sudiartha, 2018). Sudarsono dan Sudiyatno (2016) menyatakan suatu negara yang mempunyai tingkat inflasi menurun merupakan sinyal yang positif bagi investor seiring dengan turunnya risiko daya beli uang dan resiko penurunan pendapatan riil. Penelitian Kurniasari, dkk (2018) serta Geriadi dan Wiksuana (2017) menyatakan bahwa inflasi berpengaruh negatif terhadap return saham.Hikmawati dkk (2018) menyatakan penurunan inflasi dapat memberikan peningkatan terhadapcapital gain (keuntungan) perusahaan sehingga menyebabkan bertambahnya keuntungan yang diperoleh investor.

Investor yang cenderung melakukan analisis fundamental sebelum memutuskan berinvestasi, khususnya investor yang memperhatikan ROE dan DPR dari suatu saham juga akan cenderung mempertimbangkan tingkat inflasi yang terjadi. Inflasi yang rendah akan memperkuat keinginan investor untuk berinvestasi pada suatu saham setelah memperhatikan fundamental perusahaan berupa ROE dan DPR. Sebaliknya jika tingkat inflasi tinggi akan memperlemah keinginan investor untuk berinvestasi meskupun fundamental dari perusahaan yang berupa ROE dan DPR menunjukkan angka yang baik.

Berdasarkan latar belakang tersebut maka rumusan masalah yang diajukan dalam penelitian ini adalah:

1) Apakah Dividend Payout Ratio (DPR) berpengaruh terhadap harga saham perusahaan LQ45 yang terdaftar di Bursa Efek Indonesia periode 2018 - 2019?

2) Apakah Return on Equity (ROE) berpengaruh terhadap harga saham perusahaan LQ45 yang terdaftar di Bursa Efek Indonesia periode 2018 - 2019?

3) Apakah inflasi memoderasi pengaruh Dividend Payout Ratio (DPR) terhadap harga saham perusahaan LQ45 yang terdaftar di Bursa Efek Indonesia periode 2018 - 2019?

4) Apakah inflasi memoderasi pengaruh Return on Equity (ROE) terhadap harga saham perusahaan LQ45 yang terdaftar di Bursa 
Efek Indonesia periode 201782019 ?

\section{TINJAUAN PUSTAKA \\ Pasar Modal}

Pasar modal merupakan tempat bertemunya pembeli dan penjual dengan risiko laba dan rugi (Jogiyanto, 2010). Produk yang dijual di pasar modal dapat berupa saham atau obligasi. Sunariyah (2004) mendefinisikan pasar modal sebagai suatu tempat yang disediakan untuk melakukan transaksi jual-beli atas saham, obligasi dan jenis surat berharga lainnya dengan memakai jasa para perantara efek. Menurut Herve dan Yao (2011), pasar modal merupakan tempat memperoleh pinjaman dana jangka panjang yang digunakan oleh industri dan perdagangan terutama untuk investasi tetap. Menurut Undang-Undang Pasar Modal No.8 tahun 1995, pasar modal merupakan suatu kegiatan yang bersangkutan dengan penawaran umum dan perdagangan efek/ surat berharga, perusahaan publik yang berkaitan dengan efek yang diterbitkannya, serta lembaga dan profesi yang berkaitan dengan efek.

Pasar modal menyediakan berbagai instrumen yang dapat ditransaksikan, antara lain (Jogiyanto, 2010):

1) Saham

2) Obligasi

3) Waran

4) Right (Sertifikat Bukti Right)

5) Reksa dana

\section{Inflasi}

Inflasi merupakan suatu proses naiknya harga-harga secara umum dan secara terus menerus (kontinu). Inflasi juga merupakan proses menurunnya nilai mata uang secara terus menerus (kontinu). Inflasi dapat disebabkan oleh dua hal, yaitu tarikan permintaan dan desakan produksi atau distribusi. Inflasi dapat dikategorikan menjadi empat jenis, yaitu (Amilin, 2019):

a. Inflasi ringan merupakan inflasi yang terjadi jika kenaikan harga berada di bawah angka $10 \%$ setahun

b. Inflasi sedang merupakan inflasi yang terjadi jika kenaikan harga berada pada angka $10 \%-30 \%$ setahun

c. Inflasi berat merupakan inflasi yang terjadi jika kenaikan harga berada pada angka 30\%$100 \%$

d. Hiperinflasi merupakan inflasi yang tidak terkendali, terjadi jika kenaikan harga berada di atas $100 \%$ setahun.

\section{Pengembangan Hipotesis}

Divident Payout Ratio (DPR) merupakan perbandingan antara dividen dengan laba bersih yang diperoleh oleh perusahaan. DPR yang tinggi mengindikasikan bahwa perusahaan memiliki prospek yang bagus karena dapat membayar dividen dengan jumlah yang tinggi, sehingga investor akan memperoleh return saham yang tinggi. Menurut (Kasmir, 2010:37), hasil pengembalian ekuitas atau Return on Equity merupakan rasio untuk mengukur laba bersih setelah pajak dengan modal sendiri. Rasio ini menunjukkan efisiensi penggunaan modal sendiri. Jika laba bersih yang dihasilkan mengalamipeningkatan, maka nilai Return on Equity (ROE) yang dihasilkan akanmengalami peningkatan juga. Hal ini akan meningkatkan kepercayaan investor untuk menanamkan modalnya pada perusahaan tersebut. Penelitian yang dilakukan oleh Hutami (2012) 
memperoleh hasil bahwa Return on Equity (ROE) berpengaruh positif secara signifikan terhadap harga saham. Inflasi adalah kecenderungan naiknya harga-harga barang dan jasa secara umum dan secara kontinu. Kenaikan harga dari satu atau dua barang saja tidak dapat disebut sebagai inflasi kecuali bila kenaikan harga itu meluas kepada barangbarang yang lain. Inflasi merupakan salah satu faktor yang mempengaruhi pergerakan harga saham jika dilihat dari kondisi makro ekonomi (Ningsih dan Waspada, 2018). Penelitian yang dilakukan oleh Hanafiah, dkk. (2015) menunjukan bahwa secara parsial inflasi berpengaruh negatif secara signifikan terhadap harga saham. Investor akan mempertimbangkan tingkat inflasi yang terjadi untuk memperoleh return saham, meskipun investor yakin fundamental yang baik dari perusahaan akan memberikan return yang tinggi.

Berdasarkan uraian sebelumnya, maka hipotesis yang diajukan adalah:
H1 :Dividend Payout Ratio (DPR) berpengaruh positif terhadap return saham perusahaanLQ45 yang terdaftar di Bursa Efek Indonesia periode 2018- 2019.

$\mathrm{H} 2$ :Return on Equity (ROE) berpengaruh positif terhadap harga saham perusahaan LQ45 yang terdaftar di Bursa Efek Indonesia periode 2018- 2019.

H3 : Inflasi memoderasi pengaruh Dividend Payout Ratio (DPR) terhadap return saham perusahaan LQ45 yang terdaftar di Bursa Efek Indonesia periode 2018- 2019

H4 : Inflasi memoderasi pengaruh Return on Equity (ROE) terhadap return saham perusahaan LQ45 yang terdaftar di Bursa Efek Indonesia periode 2018- 2019

Berdasarkan hipotesis yang telah diajukan, dapat digambarkan model penelitian seperti pada Gambar 1.

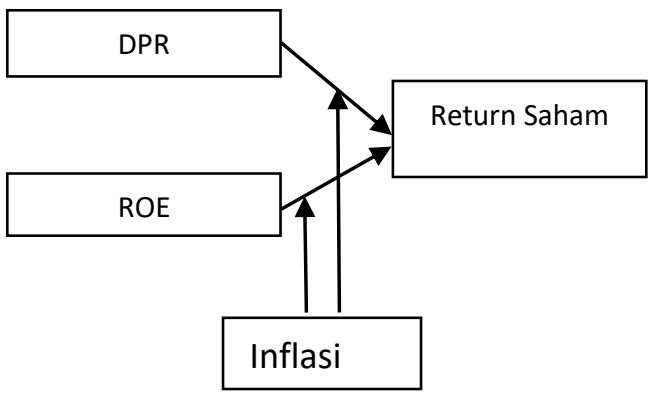

Gambar 1. Model penelitian

\section{METODE PENELITIAN \\ Sumber Data dan Metode Pengumpulan Data}

Sumber data yang digunakan dalam penelitian ini adalah sumber data sekunder. Pengumpulan data dilakukan dengan cara melakukan dokumentasi dan observasi berdasarkan data yang diperoleh.

Variabel Penelitian

1. Dividend Payout Ratio (DPR) DPRadalah rasio yang digunakan untuk mengukur besaran dividen yang akan dibagikan ke pemegang 
saham. DPR dapat dihitung menggunakan rumus:

$$
D P R=\frac{\text { Dividend per share }}{\text { Earning per share }}
$$

\section{Return on Equity (ROE)}

(ROE) atau hasil pengembalian ekuitas merupakan rasio untuk mengukur laba bersih sesudah pajak dengan modal sendiri.ROE dapat dihitung dengan menggunakan rumus:

\section{Inflasi $\left(\mathrm{X}_{3}\right)$}

$$
R O E=\frac{\text { Laba Bersih }}{\text { Total Ekuitas }}
$$

Inflasi adalah kecenderungan kenaikan harga-harga umum secara terus-menerus. Kenaikan harga dari satu atau dua barang saja tidak disebut inflasi, kecuali bila kenaikan tersebut meluas kepada sebagian besar dari harga barang-barang lainnya. Data inflasi yang digunakan adalah data yang diperoleh dari Badan Pusat Statistik (BPS) mengenai inflasi tiap tahunnya yang terjadi di Indonesia pada tahun 2017, 2018, dan 2019. Tingkatinflasi menurut IHK dapat dihitung dengan menggunakan rumus:

$$
\text { Inflasi }=\frac{I H K_{t}-I H K_{t-1}}{I H K_{t-1}}
$$

Keterangan:

Inflasi: Inflasi tahun $\mathrm{t}$

IHK: indeks harga konsumen tahun $_{\mathrm{t}}$ atau $\mathrm{t}-1$

4. Return Saham (Y)

Return saham adalah pengembalian yang diperoleh oleh investor yang berasal dari selisih antara harga jual dengan harga beli saham ditambahkan dengan dividen. Return saham diukur dengan menggunakan perhitungan berikut:

$$
\mathrm{R}=\frac{P_{t}-P_{t-1}}{P_{t-1}}+\text { yield }
$$

Keterangan :

R :Return saham

$\mathrm{P}_{\mathrm{t}} \quad$ : Harga saham tahun $\mathrm{t}$

$\mathrm{P}_{\mathrm{t}-1} \quad$ : Harga saham tahun $\mathrm{t}-1$

\section{Populasi dan Metode Penentuan} Sampel

Populasi dalam penelitian ini adalah seluruh perusahaan yang termasuk dalam Indeks LQ45 periode 2018 - 2019 yang terdaftar di Bursa Efek Indonesia (BEI). Teknik penentuan sampel yang digunakan dalam penelitian ini adalah purposive sampling dengan kriteria:

1. Perusahaan yang terdaftar di BEI dan termasuk dalam indeks LQ45 selama periode 2018-2019

2. Perusahaan yang mengeluarkan laporan keuangan audit tiap tahunnya dan dipublikasikan dari tahun 2018 - 2019.

3. Perusahaan tidak mengalami kerugian selama periode 20182019.

4. Perusahaan membayar dividen secara terus-menerus selama periode 2018-2019.

Berdasarkan kriteria yang telah ditetapkan, diperoleh jumlah sampel yang digunakan dalam penelitian ini sebanyak 40 sampel.

\section{Teknik Analisis Data}

Analisis data yang digunakan dalam penelitian ini adalah moderated regression analysis yang digunakan untuk menguji hipotesis yang diajukan dalam penelitian ini. Sebelum mengujidan menganalisis data dengan menggunakan model moderated regression analysis, maka terlebih dulu dilakukan pengujian asumsi klasik agar dapat dijadikan alat estimasiyangtidak bias jika telah memenuhi persyaratan BLUE(Best Linier Unbiased Estimator) sehingga hasil perhitungan dapat 
diinterpretasikan dengan efisien dan akurat.

\section{HASIL DAN PEMBAHASAN}

Hasil penelitian ini diperoleh dari hasil pengolahan data dengan bantuan program SPSS. Data yang diujikan telah memenuhi syarat BLUE. Hasil penelitian disajikan pada Tabel 2.

Tabel 2

Hasil Analisis Data

Coefficients $^{a}$

\begin{tabular}{|c|c|c|c|c|c|c|}
\hline & & $\begin{array}{r}\text { Unstanc } \\
\text { Coeffi }\end{array}$ & $\begin{array}{l}\text { lardized } \\
\text { cients }\end{array}$ & $\begin{array}{l}\text { Standardized } \\
\text { Coefficients }\end{array}$ & & \\
\hline & & $\mathrm{B}$ & Std. Error & Beta & $\mathrm{t}$ & Sig. \\
\hline 1 & (Constant) & .085 & .084 & & 1.016 & .316 \\
\hline & $\mathrm{X} 1$ & -6.679 & 3.924 & -2.876 & -1.702 & .098 \\
\hline & $\mathrm{X} 2$ & 3.658 & 1.779 & 2.987 & 2.056 & .047 \\
\hline & $\mathrm{X} 1 \mathrm{X} 3$ & 1.896 & 1.294 & 2.485 & 1.465 & .152 \\
\hline & $\times 2 \times 3$ & -1.177 & .605 & -2.761 & -1.945 & .060 \\
\hline
\end{tabular}

a. Dependent Variable: $Y$

Pengujian hipotesis pertama dilakukan untuk mengetahui pengaruh Divident Payout Ratio (DPR) terhadap Return Saham pada perusahaan LQ45 periode 2018-2019. Hasil analisis data pada Tabel 3 menunjukkan nilai significant variable DPR sebesar 0,098. Hal ini berarti Divident payout ratio tidak berpengaruh terhadap return saham. Return saham yang diperoleh oleh investor dapat berasal dari dividen dan capital gain. Investor yang ingin berinvestasi jangka panjang akan mempertimbangkan tingkat dividen yang diberikan oleh perusahaan yang diinvestasikan. Namun dalam kondisi ekonomi yang bergejolak, tidak sedikit investor yang memilih untuk menginvestasikan uangnya pada instrumen keuangan selain saham, atau bahkan lebih memilih untuk memegang uang cash daripada berinvestasi. Selama tahun 2018, terjadi perang dagang antara China dan Amerika Serikat. Hal tersebut tentu saja berimbas ke Negara-negara lain termasuk Indonesia, mengingat China dan Amerika Serikat merupakan dua Negara raksasa yang sangat berpengaruh di dunia. Perang dagang yang terjadi antara kedua Negara tersebut memberikan imbas ke IHSG, dimana selama tahun 2018 IHSG mengalami minus $2,54 \%$ dari awal Januari sampai Desember 2018. Hal ini berarti banyak investor yang menarik uangnya dari saham-saham yang terdaftar di BEI sehingga menyebabkan IHSG mengalami penurunan. Di tengah ketidakpastian ekonomi akibat perang dagang, investor lebih memilih untuk melakukan trading daripada berinvestasi jangka panjang. Sehingga investor tidak lagi memperhatikan tingkat dividen yang ditawarkan oleh perusahaan untuk memperoleh return, namun lebih memperhatikan pergerakan saham secara teknikal. Di 
samping itu pemegang saham yang belum memerlukan uang akan lebih memilih jika perusahaan menahan sebagian laba untuk menjadi laba ditahan daripada dibagikan sebagai dividen tunai (Puspitasari dan Purnamasari, 2013).

Pengujian hipotesis kedua dilakukan untuk menguji pengaruh Return on Equity (ROE) terhadap return saham pada perusahaan LQ45 periode 2018-2019. Hasil analisis menunjukkan nilai signifikansi sebesar 0,047 dengan nilai koefisien regresi sebesar 3,658 yang memiliki tanda positif. Hal ini berarti ROE berpengaruh positif dan signifikan terhadap return saham. ROE merupakan rasio profitabilitas yang digunakan untuk mengukur kemampuan perusahaan dalam menghasilkan laba bersih bagi para investor atau pemilik dari investasi pemegang saham perusahaan dengan menggunakan modal sendiri. Dalam melakukan investasi, para investor akan mempertimbangkan nilai ROE yang dimiliki oleh perusahaan untuk menilai return saham yang akan dihasilkan. Semakin tinggi tingkat ROE yang dihasilkan oleh perusahaan maka akan semakin tinggi juga return saham yang diberikan oleh perusahaan tersebut, sehingga tidak jarang investor akan melakukan analisis terhadap ROE perusahaan sebelum memutuskan untuk berinvestasi.

Pengujian hipotesis ketiga dilakukan untuk menguji moderasi inflasi terhadap hubungan DPR dan return saham pada perusahaan LQ45 periode 2018-2019. Hasil analisis menunjukkan nilai signifikansi sebesar 0,152. Hal ini menunjukkan bahwa inflasi tidak memoderasi pengaruh DPR terhadap return saham.
Investor jangka panjang memiliki pemikiran bahwa return yang diterima melalui saham lebih tinggi dibandingkan dengan kenaikan inflasi yang akan terjadi. Sehingga fluktuasi inflasi tidak lagi menjadi hal yang diperhatikan oleh investor yang sudah memilih saham sebagai instrumen investasinya. Investor hanya fokus pada perolehan deviden yang dihasilkan. Selama tahun 2018-2019 rata-rata DPR yang diberikan oleh perusahaan pada indeks LQ 45 menunjukkan nilai yang tidak sedikit, yaitu rata-rata nilai DPR adalah 0,34 (34\%). Nilai tersebut merupakan nilai pengembalian yang lumayan tinggi bagi investor, apalagi jika investor bersifat devidend hunter.

Pengujian hipotesis keempat dilakukan untuk menguji moderasi inflasi terhadap hubungan ROE dan return saham pada perusahaan LQ45 periode 2018-2019. Hasil analisis menunjukkan nilai signifikansi sebesar 0,060. Hal ini menunjukkan bahwa inflasi tidak memoderasi pengaruh ROE terhadap return saham. Investor jangka Panjang berfokus pada pengembalian jangka panjang, dimana mereka memiliki keyakinan bahwa investasi pada saham akan memberikan return yang lebih tinggi dibandingkan inflasi yang terjadi.

Inflasi pada periode penelitian ini berada pada kategori inflasi ringan yakni dengan rata- rata $2,93 \%$ atau dibawah 10\%. Inflasi dengan laju pertumbuhan yang berlangsung secara perlahan dan berada dibawah $10 \%$ yang artinya tergolong stabil dan terkendali. Inflasi yang rendah dan stabil tidak berdampak pada tingkat profitabilitas perusahaan sehingga investor tidak terlalu memperhatikan inflasi yang terjadi dalam memperoleh return saham. 


\section{SIMPULAN DAN SARAN Simpulan}

Berdasarkan hasil pengolahan data dan pembahasan yang telah diuraikan sebelumnya, maka dapat diambil simpulan sebagai berikut:

1) DPR tidak berpengaruh terhadap Return Saham pada perusahaan LQ45 periode 2018-2019

2) ROE berpengaruh positif dan signifikan terhadap Return Saham pada perusahaan LQ45 periode 2018-2019.

3) Inflasi tidak memoderasi pengaruh DPR terhadap Return Saham pada perusahaan LQ45 periode 2018-2019.

4) Inflasi tidak memoderasi pengaruh ROE terhadap Return Saham pada perusahaan LQ45 periode 2018-2019.

\section{Saran}

Berdasarkan penelitian yang telah dilakukan, maka saran yang dapat diberikan oleh peneliti antara lain:

1) Penelitian berikutnya dapat meneliti perusahaan pada indeks lain yang memiliki tingkat DPR lebih bervariasi sehingga dapat dijadikan perbandingan dengan hasil penelitian ini.

2) Perusahaan disarankan untuk menjaga konsistensi tinglat ROE yang dihasilkan oleh perusahaan karena menjadi salah satu faktor yang mempengaruhi return saham yang dapat menjadi pertimbangan investor dalam berinvestasi

\section{DAFTAR PUSTAKA}

Amilin. 2019. Analisis Informasi Keuangan. Edisi Kedua. Banten: Universitas Terbuka

Devi, Ni Nyoman S.J.P. dan Artini, L. G. Sri. 2019. Pengaruh ROE,
DER, PER, dan Nilai Tukar terhadap Return Saham. EJurnal Manajemen. 8(7)

Fidrian, Refi Cipta. Djaelani, Abdul Kodir. Slamet, Afi Rachmat. 2018. Pengaruh Price Earning Ratio, Deviden Payout Ratio, dan Return on Equity terhadap Return Saham Perusahaan Manufaktur yang Terdaftar di Bursa Efek Indonesia. EJurnal Riset Manajemen Prodi Manajemen Fakultas Ekonomi Unisma

Geriadi, Made Ayu Desy. dan Wiksuana, I Gusti Bagus. 2017. Pengaruh Inflasi terhadap Return Saham pada Perusahaan Properti dan Real Estate yang Terdaftar di Bursa Efek Indonesia (Risiko Sistematis dan Profitabilitas sebagai Variabel Mediasi). EJurnal Ekonomi dan Bisnis Universitas Udayana. 6(9)

Hanafiah, M. S, Nengah Sudjana, dan Sri Sulasmiyati. 2015. Pengaruh Harga Minyak Dunia, Nilai Tukar Rupiah Terhadap Dollar, Dan Tingkat Inflasi Terhadap Harga Saham (Studi Pada PT Bumi Resources Minerals Tbk Periode Januari 2008Desember 2013). Jurnal Administrasi Bisnis, 28(2)

Herve, D. B. Dan Yao, S. 2011. Management of Stock Price and it Effect on Economic Growth: Case Study of West African Financial Markets. International Journal of 
Business and Management, $6(2)$

Hikmawati, Ningsih. Adi Wiratno. Suyanto. Darmansyah. 2018. Pengaruh Return On Assets, Return On Equity, Debt To Equity Ratio, Inflasi, Dan Suku Bunga Terhadap Return Saham Pada Perusahaan Manufaktur Di Bursa Efek Indonesia (Studi Empiris Pada Perusahaan Secondary Sectors Periode 2010-2015). Jurnal Ilmiah Akuntansi Kesatuan, 6(1)

Hutami, Rescyana Putri. 2012. Pengaruh Dividend per Share, Return on Equity dan Net Profit Margin terhadap Harga Saham Perusahaan Industri Manufaktur yang Tercatat di Bursa Efek Indonesia Periode 2006-2010. Jurnal Nominal, 1(1)

Jogiyanto. 2010. Metodologi Penelitian Bisnis. Yogyakarta: BPFE

Kasmir. 2010. Analisis Laporan Keuangan. Cetakan Keempat. Jakarta: PT.Raja Grafindo Persada

Kurniasari, Wulan. Wiratni, Adi. Dan Yusuf, Muhammad. 2018. Pengaruh Inflasi Dan Suku Bunga Terhadap ReturnSaham Dengan Profitabilitas Sebagai Variabel Intervening di Perusahaan YangTerdaftarDi Bursa Efek IndonesiaTahun 2013-2015. JournalOf Accounting Science, 2(1)
Ningsih, M. M. dan Waspada, I. 2018. Pengaruh Bi Rate Dan Inflasi Terhadap Indeks Harga Saham Gabungan (Studi Pada Indeks Properti, Real Estate, dan Building Construction, di BEI Periode 2013-2017). Manajerial: Jurnal Manajemen dan Sistem Informasi, 17(2)

Pratiwi, Putri. 2015. Pengaruh Kebijakan Deviden terhadap Return Saham pada Perusahaan Sektor Industri Barang Konsumsi yang Terdaftar di Bursa Efek Indonesia. Jurnal Financial, 1(1)

Puspitasari, Anggraeni. Dan Purnamasari, Linda. 2013. Pengaruh Perubahan Dividend Payout Ratio dan Dividend Yield terhadap Return Saham (Studi pada Perusahaan Manufaktur di Bursa Efek Indonesia. Journal of Business and Banking, 3(2)

Sudarsono, Bambang. dan Sudiyatno, Bambang. 2016. FaktorFaktor yang Mempengaruhi Return Saham pada Perusahaan Properti dan Real Estate yang Terdaftar pada Bursa Efek Indonesia Tahun 2009-2014. Jurnal Bisnis dan Ekonomi (JBE), 23(1)

Sunariyah. 2004. Pengantar Pengetahuan Pasar Modal. Edisi Keempat. Yogyakarta: UPP AMP YKPN

Suriyani, Ni Kadek. dan Sudiartha, Gede Mertha. 2018. Pengaruh 
Journal of Applied Management and Accounting Science. (JAMAS)

(Ni Nyoman Sri Rahayu Trisna Dewi 132 - 142)

Vol 2, No 2, Juni 2021

Tingkat Suku Bunga, Inflasi dan Nilai Tukar terhadap Return Saham di Bursa Efek Indonesia. E-Jurnal Manajemen Unud, 7(6)

Tandelilin, Eduardus. 2010. Portofolio dan Investasi (Teori dan Aplikasi). Edisi Pertama. Kanisius. Yogyakarta: BPFE.

Undang-Undang Pasar Modal No.8 tahun 1995Wijaya, Rendi. 2019. Analisis Perkembangan Return on Assets (ROA) dan Return on Equity (ROE) untuk Mengukur Kinerja Keuangan. Jurnal Ilmu Manajemen, 9(1) 